\title{
The Influence of the Lotic and Lentic Stretches on the Zooseston Flux through the Plitvice Lakes (Croatia)
}

\author{
M. Špoljar*, I. Habdija, B. Primc-Habdija
}

University of Zagreb, Faculty of Science, Division of Biology, Department of Zoology, Rooseveltov trg 6, HR-10 000 Zagreb, Croatia.

\begin{abstract}
We studied the influence of lotic and lentic stretches on zooseston flux in the karstic barrage Plitvice Lakes (Croatia). Three sampling stretches were selected: 1) a channel with low inclination; 2) water flow through a deep lake (retention), and 3) a channel with cascades and sharp inclination. At all sampling points of the three stretches, zooseston reached maximum abundance in September (up to $147.39 \mathrm{ind} / \mathrm{m}^{3}$ ). Rotifers dominated in both zooseston abundance (58 to $80 \%$ ) and diversity (66 taxa), followed by crustaceans (23 taxa), predominantly Cladocera and Copepoda. Kruskal-Wallis test suggest statistically significant differences between the lentic and both lotic stretches in the biomass net flux of euplanktonic organisms. The net flux of benthic organism biomass and changes in the biodiversity index were significantly different between the lentic stretch and lotic stretch with high inclination. Lotic stretches had a greater influence on the increase of abundance and biomass of benthic and semiplanktonic organisms than on the decrease of euplanktonic organisms. Principal Components Analysis of the species environment relationship explained $66 \%$ of the variance by the two first axes, where axis 1 accounted for $39 \%$ and axis 2 accounted for $27 \%$ of the variance. Oligochaets, insect larvae, nematodes and total zooseston were associated with component 1 , showing that their biomass was negatively correlated with discharge and dissolved oxygen concentration and positively correlated with temperature. Other taxa showed a similar correlation with component 1. Biomass of Cladocera, Copepoda, T. birostris, Polyarthra spp., K. cochlearis and rotifers was associated with component 2 , and positively correlated with food resources such as chl- $a$, POM and DOM. The inference is that zooseston flux through Plitvice Lakes is a function of the hydrological and physiographical features of the stretches, as well as food resources from the lakes.
\end{abstract}

Keywords: karstic lake, lotic, lentic, zooseston, rotifers

\section{Introduction}

Seston (rheoseston) consist in organic and inorganic particles in the current of running water, of both autochtonous and allochtonous origin, dead or alive. Zooseston represents its faunistic component (Breitig \& Tuempling 1982). The majority of the organisms in zooseston originate from the benthos (bed or periphyton), and/or the plankton (from upstream lakes, accumulation).

Contrary to other studies, where zooseston from long lotic sections flows into a short lentic area (lake, dam, reservoir) (Lair 1980, Tubbing et al. 1994, Leonard \& Paerl 2005), the present study was conducted in a cascade system of karstic barrage lakes connected with short lotic stretches (channels, waterfalls). The precipitation of calcium carbonate in the form of tufa or lake sediment in the Plitvice Lakes is very intensive, and re-

\footnotetext{
* Corresponding author : E-mail : mspoljar@zg.biol.pmf.hr
}

quires the fulfilment of certain conditions: saturation index in respect to calcium carbonate $>3, \mathrm{pH}$ values $>$ 8 and concentration of dissolved organic matter $<10$ $\mathrm{mg} / \mathrm{l}$ (Srdoč et al. 1985). The same authors established that the base for tufa deposition must be of organic origin (microorganism skeletal parts). Nevertheless, anthropogenic impacts in the area around the lakes (tourism infrastructure, agriculture, communal sewage) counter the required conditions and accelerates eutrophication processes in the lakes.

The qualitative and quantitative zooseston flux in the Plitvice Lakes was analysed to estimate the zooseston contribution in the sedimentation of organic matter in the lakes and on the barriers. Second, in order to determine the composition of rotifer and crustacean species, it is important to establish the resistance of euplanktonic species in the lotic environment. Species composition, with reference to functionnal feeding groups (microfilter-feeders and macrofilter-feeders), reflect the 
Table 1. Morphometrical features, physical and chemical parameters of the investigated stretches

\begin{tabular}{|c|c|c|c|c|c|c|}
\hline Name of the stretch & & BL1-BL2 & \multicolumn{2}{|c|}{ BVJ-BLG } & \multicolumn{2}{|l|}{ BM1-BM2 } \\
\hline Bottom cover & & $\begin{array}{c}\text { sand, gravel, few cataracts with } \\
\text { moss overgrowth with sciophylic } \\
\text { species genera Bryum and } \\
\text { Cratoneurum }\end{array}$ & \multicolumn{2}{|c|}{ sand, silt } & $\begin{array}{l}\text { sand, gravel, barrier moss } \\
\text { overgrowth with sciophylic } \\
\text { species }\end{array}$ & \\
\hline Width (m) / Depth (m)* & & $7 \mathrm{~m} / 1 \mathrm{~m}$ & \multirow{2}{*}{\multicolumn{2}{|c|}{$607.5-586$}} & $2.5 \mathrm{~m} / 0.5 \mathrm{~m}$ & \\
\hline Altitude ( $m$ a.s.l.) & & $636.6-633.8$ & & & $563.5-541$ & \\
\hline Length $(\mathrm{m})$ & & 280 & \multicolumn{2}{|c|}{600} & 145 & \\
\hline Inclination (\%) & & 1 & \multicolumn{2}{|c|}{3.6} & 7.6 & \\
\hline Parameter & Min & Max & Min & Max & Min & Max \\
\hline Temperature $\left({ }^{\circ} \mathrm{C}\right)$ & 3 & 18.8 & 3 & 20.6 & 3 & 21.8 \\
\hline Dissolved oxygen $\left(\mathrm{mg} \mathrm{O}_{2} / \mathrm{l}\right)$ & 7.5 & 13.0 & 7.9 & 14.5 & 7.5 & 13.6 \\
\hline $\mathrm{pH}$ & 7.6 & 8.5 & 7.7 & 8.6 & 7.7 & 8.6 \\
\hline Alkalinity $\left(\mathrm{mg} \mathrm{CaCO}_{3} / \mathrm{l}\right)$ & 215.8 & 256.7 & 210 & 251 & 186.67 & 245 \\
\hline SRP (mg P/l) & 0.01 & 0.04 & 0.01 & 0.04 & 0.01 & 0.04 \\
\hline $\mathrm{COD}_{\mathrm{KMnO}_{4}}\left(\mathrm{mg} \mathrm{O}_{2} / \mathrm{l}\right)$ & 1 & 3.1 & 1 & 2.5 & 0.9 & 2.8 \\
\hline Chl- $a \times 10^{3}\left(\mu \mathrm{g} / \mathrm{m}^{3}\right)$ & 0.2 & 4.6 & 0.1 & 1.7 & 0.3 & 1.3 \\
\hline $\begin{array}{l}\mathrm{POM}\left(\mathrm{mg} \text { AFDW } / \mathrm{m}^{3}\right) \\
\text { Heterotrophic bacteria } \times 10^{6}\end{array}$ & 42,5 & 207,0 & 42,5 & 270 & 47,5 & 193 \\
\hline CFU $/ \mathrm{m}^{3}$ & 130 & 2200 & 50 & 1320 & 50 & 1600 \\
\hline
\end{tabular}

*Average values for width and depth

trophic state of the hydrosystem (Karabin 1985). Third, we evaluated the quality and quantity of zooseston, due to its importance as a food source for macrozoobenthic filterers (bivalves, insect larvae of Trichoptera, Ephemeroptera and Simuliidae), juvenile fish and small fish species (Habdija et al. 1994, Welker \& Walz 1998, Descy et al. 2003). The objectives of this study were thus (i) to determine the influence of lotic/lentic stretches on the quality and quantity of zooseston advective flux, and (ii) to establish the influence of environmental factors on the zooseston.

\section{Study area}

The investigation of zooseston flux was conducted in Plitvice Lakes National Park. This area belongs to the karstic region of the NW Dinarid Mountains, and has both surface and subterranean drainage systems. Figure 1 shows the distribution of the sixteen lakes, which are divided into Upper and Lower Lakes. The Upper Lakes are situated in dolomite rock, and the Lower Lakes in well-bedded rudist limestone in the canyon of the Korana River. The lakes are oligotrophic and dimictic, and water flows from one lake into another over barriers with different forms of channels, cascades or waterfalls from the highest, Prošće Lake at an altitude of $637 \mathrm{~m}$, to the lowest, Novakovića Brod
Lake and the Sastavci waterfalls at an altitude of 503 $\mathrm{m}$. Samples were collected at three stretches that vary in terms of physiography and hydrology (Table 1, Fig. 1).

1. Stretch BL1-BL2: The channel on the barrier with low inclination (Barrier Labudovac 1, BL1-Barrier Labudovac 2, BL2). The starting point was BL1 (outlet of water from Prošće Lake, maximum depth $37.4 \mathrm{~m}$, area $0.68 \mathrm{~km}^{2}$, the ending point BL2 was located before the Labudovac barrier. At the beginning of the Labudovac channel, at the outlet of Prošce Lake, the bottom is covered with submerged vegetation. Trees shade the majority of the channel (Table 1, Fig.1).

2. Stretch BVJ-BLG: Water flow through a deep lake (Barrier Veliko jezero, BVJ - Barrier Lake Galovac, $B L G)$. From the starting point, BVJ, water flows over a high barrier and through the deep Galovac Lake (maximum depth $25 \mathrm{~m}$, area $0.13 \mathrm{~km}^{2}$ ). The ending point, BLG, was situated at the outflow of water from Galovac Lake (Table 1, Fig. 1).

3. Stretch BM1-BM2: Channel with cascades and sharp barrier inclination (Barrier Milanovac 1, BM1Barrier Milanovac 2, BM2). The starting point, BM1, was situated at the outflow of water from the largest and deepest lake in the Plitvice hydrosystem, Kozjak Lake (maximum depth $46.4 \mathrm{~m}$, area $0.82 \mathrm{~km}^{2}$ ), to the 


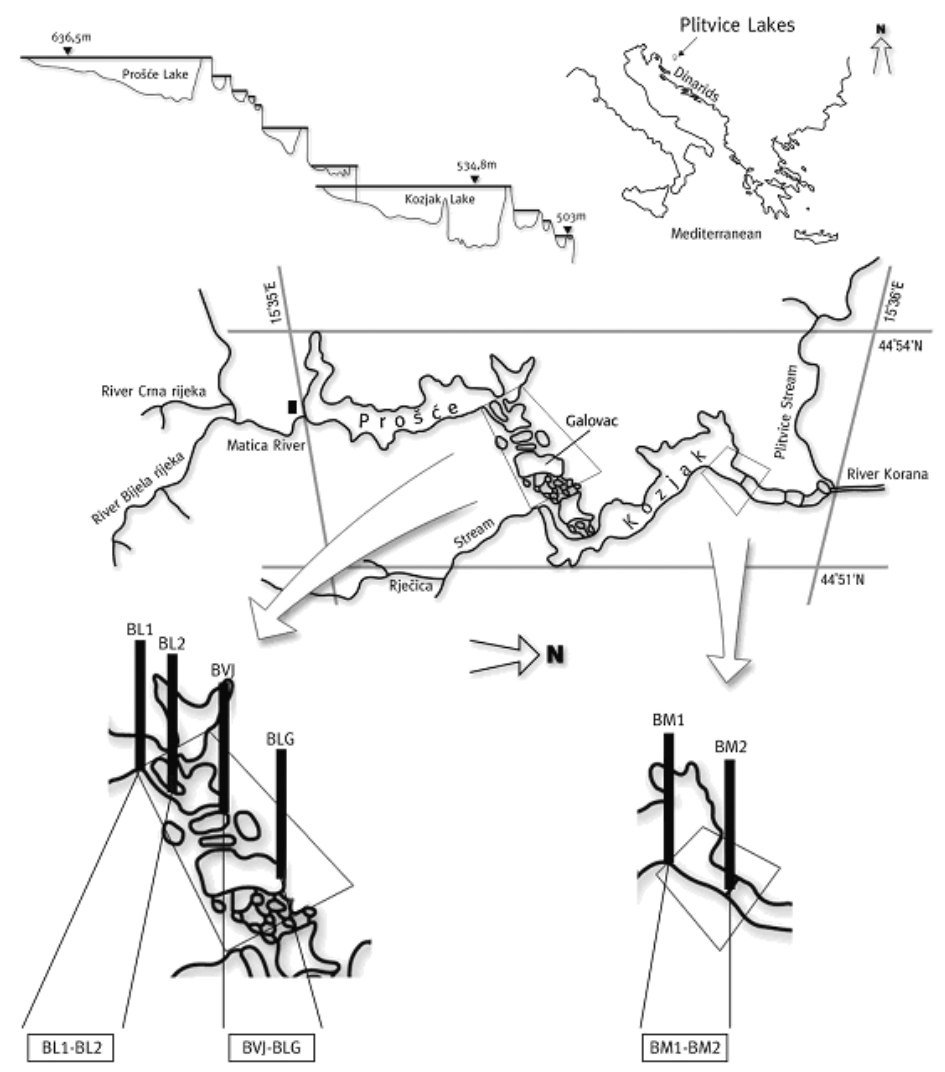

Fig. 1. Map showing the location of the Plitvice Lakes, with sampling points and investigated stretches: BL1-BL2, BVJ-BLG, BM1-BM2. The quadrangle marks hydrological station.

right border channel over the Milanovac barrier. A large area of the littoral zone was overgrown with the emergent species Typha latifolia and Cladium mariscus. At the beginning of the stretch, bed inclination was low, while about $100 \mathrm{~m}$ from the starting point, the barrier dropped relatively steeply. In this area, trees shade the channel. The ending point, BM2, was situated after the overflow of the Milanovac barrier (Table 1, Fig. 1).

\section{Materials and methods}

\section{Zooseston sampling and diversity, abundance and biomass estimation}

Samples were collected monthly from January to December 2000 (except February) in the Plitvice Lakes at the starting and ending points of the three investigated stretches. At each site, $200 \mathrm{~L}$ of water were filtered through a plankton net (mesh $26 \mu \mathrm{m})$. Filtrates were collected in $150 \mathrm{~mL}$ bottles, and transported in coolers to the lab. Analysis of seasonal changes of zooseston quality and quantity included a size fraction between 50 to $500 \mu \mathrm{m}$ for microzooseston and between 500 and $1000 \mu \mathrm{m}$ for mesozooseston (Breitig \& Tuempling 1982). Identification was carried out on live material, which was later fixed in $4 \%$ formaldehyde. Considering that the majority of organisms belonged to plankton, we used the plankton enumeration technique in the Sedgewick-Rafter cell under the Opton-Axiovert 35 inverted microscope.

Rotifers were determinated to the species or genus level according to Voigt \& Koste (1978). Bdelloid rotifers were counted but not determinated. The densities of Polyarthra dolichoptera and P. vulgaris were aggregated as a single category due to difficulties in distinguishing these closely related species. Crustaceans were determinated to the species or genus level accor- 
ding to Einsle (1993), and belonged primarily to the Cladocera and Copepoda. The fewest crustaceans belonged to the Ostracoda, and these were not determinated. Of the Protozoa, members of Sarcodinea and Ciliata were analysed and determined to genera, rarely to species (Ogden \& Hedley 1980, Foissner \& Berger 1996). Cnidaria, Nematodes, Gastrotricha, Oligochaeta, Tardigrada, Chelicerata (Hydrachnida) and insect larvae (Chironomida, Plecoptera, Trichoptera) were not determinated at lower taxonomic levels.

Biomass (dry weight) of rotifers, cladocerans and copepods in seston was calculated according to Dumont et al. (1975) and Malley et al. (1989). Protozoan biomass was estimated by assuming biovolume according to geometric shapes and converted to biomass using the conversion factor: $1 \mathrm{~mm}^{3}=10^{-6} \mathrm{mg}$ of dry biomass (Gilbert et al. 1998). Macroinvertebrate biomass was determined after being oven dried $\left(104^{\circ} \mathrm{C}\right)$. Measurements were taken on up to 30 randomly-selected individuals per taxon.

\section{Environmental variables and food resources}

Alkalinity and soluble reactive phosphorous (SRP) were analysed according to APHA (1985). Field instruments were employed to measure temperature, oxygen concentration (WTW OXI 330) and pH (WTW 330i). Data for daily water discharge were obtained from the State Meteorological and Hydrological Service, and for the year 2000 were available only at the Plitvički Ljeskovac hydrological station (Fig. 1).

The following items were considered as food supply: algae (measured as chlorophyll- $a$ concentration), particulate organic matter (POM, measured as AFDW), dissolved organic matter (DOM, measured as $\mathrm{COD}_{\left(\mathrm{KMnO}_{4}\right)}$ ) and heterotrophic bacteria (CFU, $22^{\circ} \mathrm{C} / 72 \mathrm{~h}$ ). Ethanol extraction without phepohytine (Nusch 1980) was used to estimate chlorophyll-a (chl- $a$ ). For POM estimation, $200 \mathrm{~L}$ of water were filtered through the plankton net (mesh $26 \mu \mathrm{m}$ ); this implies that ultra fine particulate organic matter (UPOM) was considered. Samples were dried at $104^{\circ} \mathrm{C} / 4 \mathrm{~h}$ and ashed at $600^{\circ} \mathrm{C} / 6 \mathrm{~h}$.

\section{Data analysis}

The flux of zooseston biomass (t/year) was considered to be the product of organism biomass and discharge. Species diversity $\left(H^{\prime}\right)$ for taxa in zooseston was calculated using the Shannon-Wiener Index (Shannon \& Weaver 1949).

In order to explain the relationship between the biomass of the dominant zooseston taxa and environmen- tal variables (discharge, temperature, dissolved oxygen, chl- $a$, DOM, POM), we used Principal Component Analysis (PCA). The biomass of zooseston groups and taxa was logarithmically transformed $[\log (\mathrm{x}+1)]$ and centred prior to analysis. The correlation between biological and environmental features of zooseston was presented by plotting correlations of variables with the extracted PCA axes. The PCA was performed using PC-ORD, Multivariate analysis of ecological data, version 4 (McCune \& Mefford 1999). For other data analyses including the one-way ANOVA (environmental variables), nonparametric Mann-Whitney and Kruskal-Wallis tests (zooseston abundance and biomass), the STATISTICA software package was used (StatSoftC).

\section{Results}

\section{Environmental Conditions and Food Supply}

Low fluctuation of discharge was observed during 2000 (Fig. 2), with minimum values occurring in summer $\left(6.20 \mathrm{~m}^{3} / \mathrm{s}\right)$ and maximum values in December $\left(8.79 \mathrm{~m}^{3} / \mathrm{s}\right)$. Mean discharge was highest in winter $\left(7.80 \mathrm{~m}^{3} / \mathrm{s}\right)$ and lowest in summer $\left(6.32 \mathrm{~m}^{3} / \mathrm{s}\right)$. Statistical descriptions of other measured environmental parameters along the longitudinal profile of the Plitvice Lakes are given in Table 1. Results of the one-way ANOVA suggest that there were no significant differences in the measured parameters among the studied stretches, with the exception of chl- $a$ concentrations between stretch BL1-BL2 and the two other investigated stretches, BVJ-BLG $(p=0.012)$ and BM1-BM2 $(p=0.0031)$.

The PCA analysis of the species environment relationship explained $66 \%$ of the variance with two axes, where axis 1 accounted for $39 \%$ and axis 2 accounted for $27 \%$ of the variance (Fig. 3). Oligochaets, insect larvae, nematodes and total zooseston were associated with component 1 , showing that their biomass was negatively correlated with discharge and dissolved oxygen concentration and positively with temperature. Other taxa showed similar correlations with component 1 . The biomass of Cladocera, Copepoda, T. birostris, Polyarthra spp., K. cochlearis and rotifers was associated with component 2 and, was positively correlated with POM and DOM.

\section{Zooseston flux in the investigated stretches}

At all sampling points, maximum zooseston abundance was found in September and the highest values were found at sampling point BL2 (147.39 ind $/ \mathrm{m}^{3}$; 


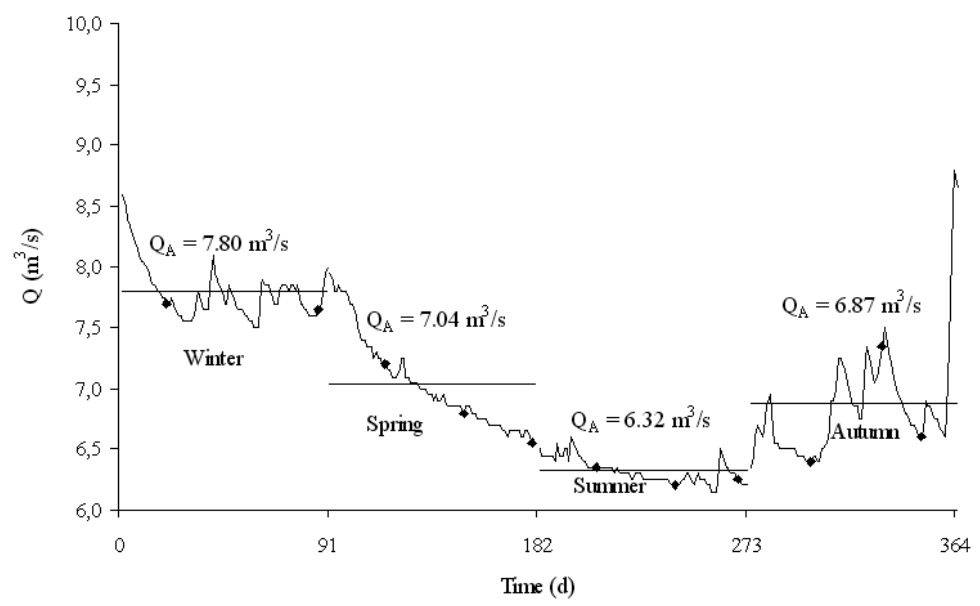

Fig. 2. Discharge regime on the hydrological station Plitvički Ljeskovac (Matica River) during the year 2000 with seasonal discharge averages $\left(\mathrm{Q}_{\mathrm{A}}\right)$. Dots mark sampling dates.

Fig. 4). Zooseston abundance was highest at the beginning of the longitudinal profile, at sampling point BL1 $\left(\right.$ mean $\left.=33.79 \mathrm{ind} / \mathrm{m}^{3}\right)$, and lowest at the end of the profile, at sampling point BM2 $\left(\right.$ mean $\left.=18.38 \mathrm{ind} / \mathrm{m}^{3}\right)$. In the investigated stretches, zooseston was dominated by euplanktonic organisms with a relative abundance of 50 to $95 \%$. Rotifers had the highest abundance and diversity in zooseston. Their relative abundance ranged

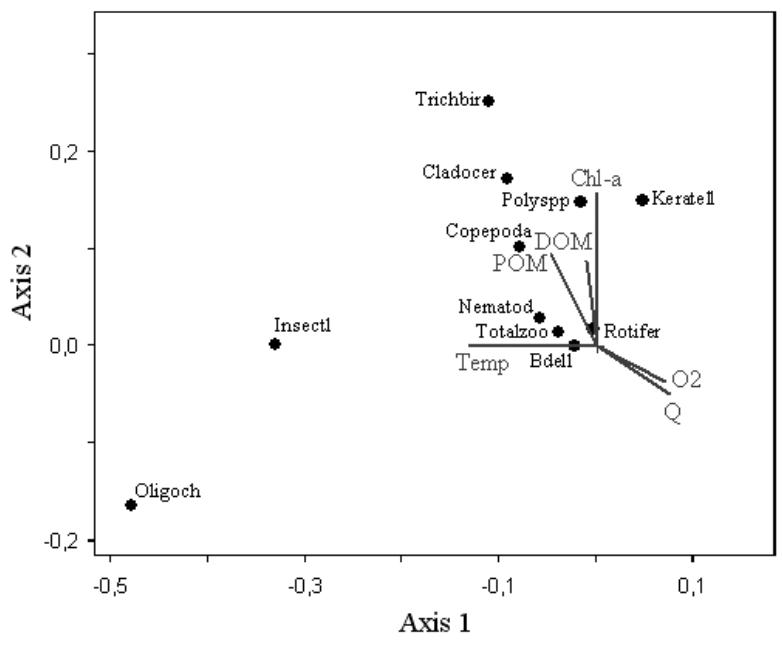

Fig. 3. PCA plot of the main zooseston species biomass against environmental variables. Bdell $=$ Bdelloidea; Cladocer $=$ Cladocera; Copepod $=$ Copepoda; Crustac $=$ Crustacea $;$ Gastrotr $=$ Gastrotri cha Insectl $=$ Insect larvae; Keratell $=K$. cochlearis $;$ Oligoch $=$ Oligochaeta Polyspp = Polyarthra spp.; Rotifer $=$ Rotifer , Sarcodin $=$ Sarcodine $;$ Tardigra $=$ Tardigrada $;$ Totalz $=$ total zooseston biomass; Trichospp $=$ Trichocerca spp. from 58 to $80 \%$ at all sampling points. Among these, 66 monogononts taxa were recognized and 55 of these were determinated to the species level (Table 2). Rotifers were the most abundant at sampling point BLG $\left(\right.$ mean $\left.=25.35 \mathrm{ind} / \mathrm{m}^{3}\right)$ and least abundant at BM2 $\left(\right.$ mean $\left.=12.97 \mathrm{ind} / \mathrm{m}^{3}\right)$. A total of 23 taxa of Crustacea were found, of which 18 were identified to the species level (Table 2). Crustaceans were most abundant at BM1 (mean $\left.=6.89 \mathrm{ind} / \mathrm{m}^{3}\right)$ and least abundant at BVJ $\left(\right.$ mean $\left.=672 \mathrm{ind} / \mathrm{m}^{3}\right)$. Their abundance quickly increased in summer and decreased afterwards (Fig. 4).

Biodiversity was the lowest in the winter at sampling point BM1 with only 10 taxa, and highest in the summer at sampling point BVJ with 58 taxa. Figure 5 shows that the lowest biodiversity index during the investigated period was noted at sampling point BM1 in April (0.9 bits/ind), while the highest was at sampling point BVJ in September (4.4 bits/ind). Oligochaets and insect larvae were most responsible for the increase of flux zooseston biomass through the lotic stretch, causing an increase by $1 \mathrm{t} /$ year on the stretch BL1-BL2 and by $5 \mathrm{t} /$ year on the lotic stretch BM1-BM2 (Fig. 6). In the flux of zooseston through the lentic stretch (BVJ-BLG), crustacean biomass showed a slight increase $(0.12 \mathrm{t} /$ year $)$.

\section{Differences in zooseston transport between the in- vestigated stretches}

The greatest changes in zooseston abundance and biomass were recorded in zooseston flux through the lotic stretch with high inclination BM1-BM2 (Table 3). This stretch showed a significant increase in the flux of semiplanktonic and benthic organism abundance, ben- 

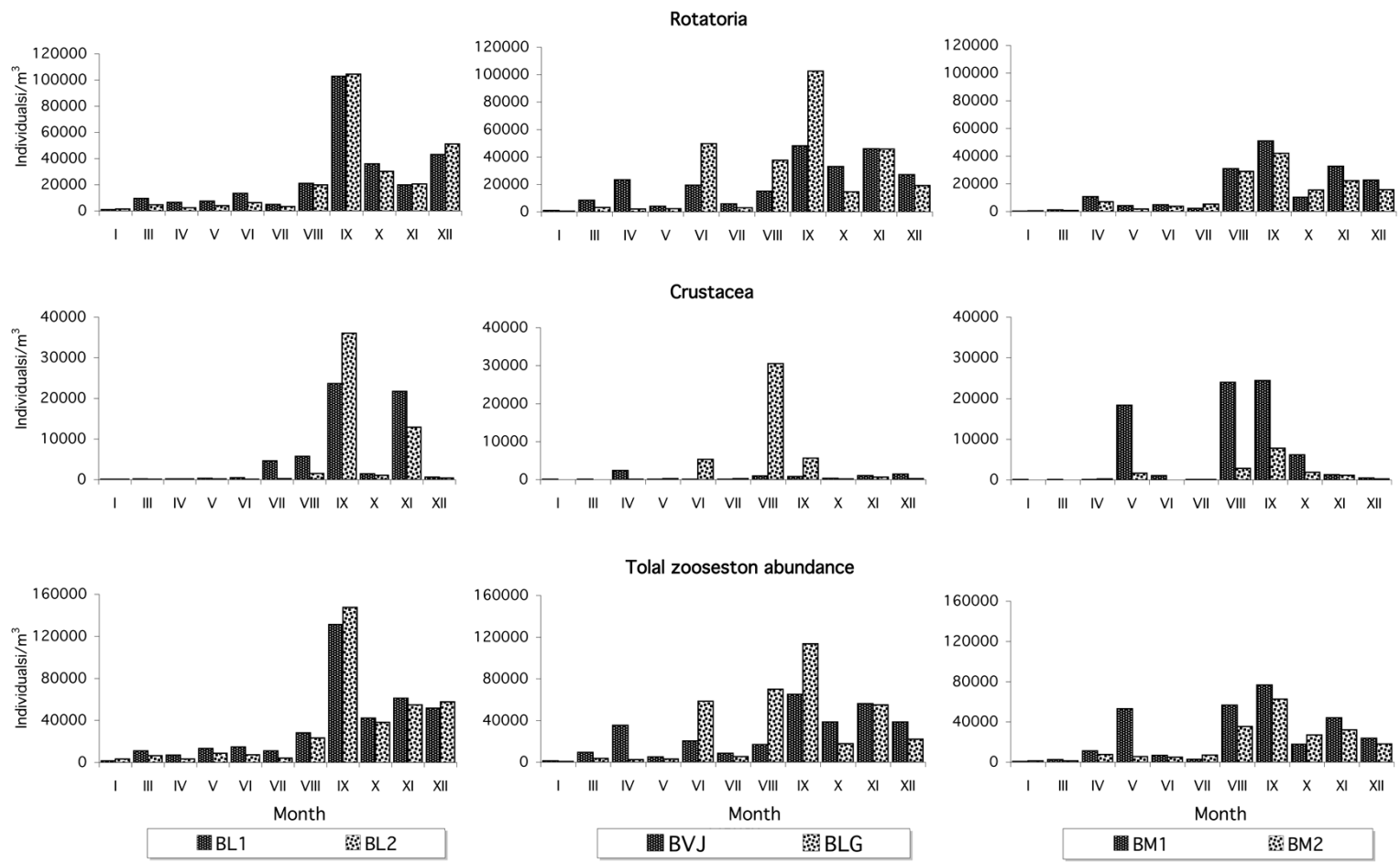

Fig. 4. Seasonal changes in Rotatoria, Crustacea, and total zooseston abundance at the starting and ending point of the investigated stretches. Months are marked in Roman numbers.

thic organism biomass and species diversity. Through the BVJ-BLG stretch, the decrease in benthic organism abundance was statistically significant.

The Kruskal-Wallis test suggested, that BVJ-BLG showed the greatest differences with the two other lotic stretches. A decrease of euplanktonic organism biomass through BVJ-BLG implied significant differences with both lotic stretches. The same test suggested that differences in benthic organism biomass and biodiversity index were statistically significant between BVJ-BLG and BM1-BM2.

\section{Discussion}

\section{Zooseston interactions with environmental varia- bles and food resources}

Hydrological features have an important impact on zooseston flux (Vadeboncoeur 1994, Pozo et al. 1994, Conde-Porcuna et al. 2002). In this study, a negative relationship was established between zooseston bio- mass and discharge. In the Plitvice Lakes hydrosystem, zooseston is primarily composed of euplanktonic organisms from the lake, and their growth is positively correlated to the water residence time, and negatively correlated to discharge (Vadeboncoeur 1994, Welker \& Walz 1998). Lower discharges and higher temperatures in summer ensure a longer water residence time, supporting the growth of species with a longer generation time (Basu \& Pick 1996).

Among the food resources, chlorophyll- $a$ concentration had the strongest influence on rotifer and crustacean abundance. A decrease in SRP was reflected on phytoplankton growth that supports zooplankton development, and enriches zooseston abundance and biomass (Špoljar 2003). Therefore, the peak abundance of zooseston and rotifers in September can be explained by the plankton growth peak in the lakes. Other authors, including de Manuel \& Jaume (1994) and Conde-Porcuna et al. (2002), obtained similar results. For instance, de Manuel \& Jaume (1994) concluded that rotifer biomass in the Guadalaquivir River (sou- 
Table 2. Rotatoria and Crustacea taxa recorded in the zooseston of the Plitvice Lakes

\section{ROTIFERA}

Family: EPIPHANIDAE

Epiphanes macrourus (Barrois \& Daday, 1894)

Family: BRACHIONIDAE

Brachionus calyciflorus (Pallas, 1766)

Kellicottia longispina (Kellicott, 1879)

Keratella cochlearis (Gosse, 1851)

Notholca foliacea (Ehrb., 1838)

Platyias quadricornis (Ehrb., 1832)

Family: EUCHLANIDAE

Euchlanis dilatata (Ehrb., 1832)

Family: MYTILINIDAE

Mytilina ventralis (Ehrb., 1832)

Family: TRICHOTRIDAE

Trichotria pocillum (O. F. M., 1776)

Trichotria tetractis (Ehrb., 1830)

Macrochaetus subquadratus (Perty, 1850)

Family: COLURELLIDAE

Colurella obtusa (Gosse, 1886)

Colurella uncinata (O. F. M., 1773)

Lepadella ehrenbergi (Perty, 1850)

Lepadella patella (O. F. M., 1786)

Squatinella mutica (Ehrb., 1832)

Family: LECANIDE

Lecane flexilis (Gosse, 1889)

Lecane luna (Mueller, 1776)

Lecane lunaris (Ehrb., 1832)

Family: PROALIDAE

Proales spp.

Family: NOTOMMATIDAE

Cephalodella gibba (Ehrb., 1838)

Cephalodella spp.

Monommata aequalis (Ehrb., 1832)

Notommata spp.

Taphrocampa sp.

Scaridium longicaudum (O. F. M., 1786)

Family: TRICHOCERCIDAE

Trichocerca birostris (Minkiewicz, 1900)

Trichocerca elongata (Gosse, 1886)

Trichocerca sp.

Family: GASTROPODIDAE

Ascomorpha ecaudis (Perty, 1850)

Ascomorpha ovalis (Bergendahl, 1892)

Gastropus stylifer (Imhof, 1891)
Family: ASPLANCHNIDAE

Asplanchna priodonta (Gosse, 1850)

Family: DICRANOPHORIDAE

Dicranophorus spp.

Encentrum sp.

Paradicranophorus hudsoni (Glascott, 1893)

Family: FLOSCULARIIDAE

Ptygura sp.

Family: TESTUDINELLIDAE

Testudinella patina (Hermann, 1783)

Pompholyx complanata (Gosse, 1851)

Family: COLLOTHECIDAE

Collotheca mutabilis (Hudson, 1885)

Family: SYNCHAETIDAE

Polyarthra dolichoptera (Idelson, 1925 )

Polyarthra vulgaris (Carlin, 1943)

Synchaeta pectinata (Ehrb., 1832)

Synchaeta stylata (Wierzejski, 1893)

Synchaeta tremula (O. F. M., 1786)

Ploesoma hudsoni (Imhof, 1891)

CRUSTACEA-CLADOCERA

Alona costata (Sars, 1862)

Alona rectangula (Sars, 1861)

Alona spp.

Alonella nana (Baird, 1850)

Bosmina longirostris (O. F. M., 1785)

Bythotrephes longimanus (Leydig, 1860)

Camptocercus rectirostris (Schoedler, 1862)

Ceriodaphnia quadrangula (O. F. M., 1785)

Chydorus sphaericus (O.F. M., 1785 )

Daphnia hyalina (Leydig, )

Daphnia longispina (O. F. M., 1776)

Daphnia magna (Straus, 1820)

Daphnia pulex (Leydig, 1860 )

Daphnia sp.

Kurzia latissima (Kurz, 1874)

Pleuroxus sp.

Pleuroxus truncatus (O.F. M., 1785)

Polyphemus pediculus (L., 1761)

Scapholeberis mucronata (O. F. M., 1785)

Simocephalus sp.

CRUSTACEA-COPEPODA

Canthocamptus staphylinus (Jurine, 1820)

Cyclops spp.

Thermocyclops oithonoides (Sars, 1863) 

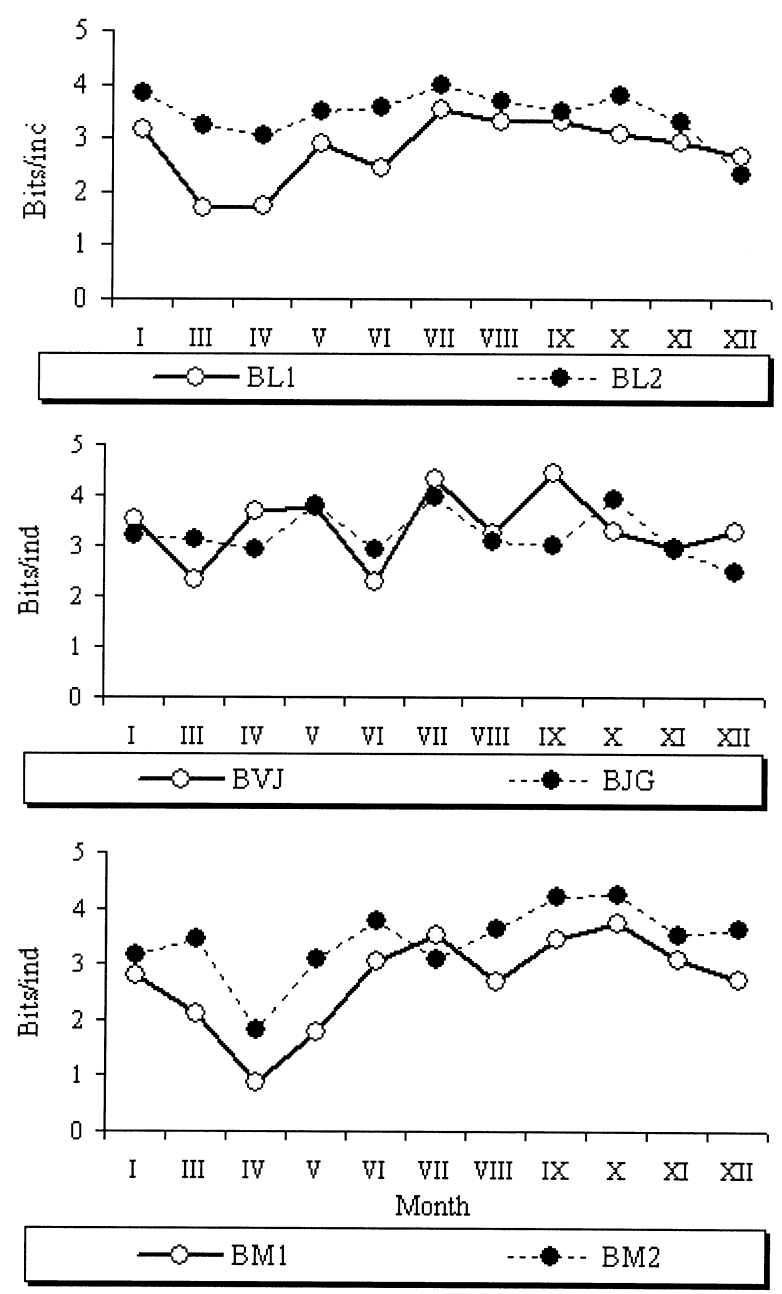

Fig. 5. Seasonal changes in Shannon-Wiener index $\left(\mathrm{H}^{\prime}\right)$ during the flux of organisms through the investigated stretches. Months are marked in Roman numbers.

thern Spain) was positively correlated with mean chl- $a$ in the period of thermal stratification. The highest zooseston abundance at the beginning of the longitudinal profile was also explained by the significantly higher concentration of chl- $a$ in the stretch BL1-BL2, in comparison to the other two stretches. Namely, the Matica River which is the main tributary of the Plitvice Lakes hydrosystem inputs higher nutrient concentrations into Prošce Lake, at the beginning of longitudinal profile. With respect to overflow effect, the higher primary and secondary production in upstream lakes can be explained by the retention of mineral salts, thereby impacting the depletion in the downstream lakes (Erben 1991, Špoljar et al. 2001).

\section{Comparison of zooseston flux through lotic and lentic stretches}

The lentic-lotic transition was characterised by the flow of water from deep lakes through a channel with low or high inclination. In the zooseston flux through the channel with low inclination (BL1-BL2), sedimentation of euplanktonic organisms prevailed in contrast to the entrance of benthic and semiplanktonic organisms in seston, suggesting low drift and erosion processes in this stretch. The abundance and biomass of small euplanktonic organisms, i.e. K. cochlearis, Polyarthra spp. and T. birostris, decreased only slightly. Namely, their low weight prevented their sedimentation in the constantly turbulent water and they remained in the seston over a longer distance (Sandlund 1982).

In the second investigated lentic-lotic transition through the channel with high inclination (BM1BM2), a decrease was recorded in the flux of euplanktonic organism biomass/abundance with an extreme increase in the flux of benthic organism biomass/abundance. First, the biomass decrease of euplanktonic organisms was caused by the sedimentation of euplanktonic crustaceans, as biomass was highest in Kozjak Lake. For instance, in the Plitvice Lakes, bryophyte mats in the channel over the barrier offer substantial refuge for small invertebrates against water current velocity (Habdija et al. 2004). Second, macroinvertebrate ingestion also resulted in a decrease of euplanktonic organism abundance/biomass, which was also supported in the study by Habdija et al. (1994). The authors reported that in the channels of the Plitvice Lakes hydrosystem, functional feeding groups of collectors (naidids, chironomids, blackfly, caddisfly larvae) and shredders (amphipod Gammarus balcanicus ScHÄFERNA) constituted the highest percentage of total macroinvertebrates. It is assumed that their ingestion impacts the loss of euplanktonic organisms from the seston, primarily small rotifer species. Furthermore, Sandlund (1982) reported that the largest species, i.e. crustaceans, were first removed from the seston flux and the highest decrease, up to $45 \%$, was observed approximately $200 \mathrm{~m}$ from the lake outlet. Conversely, the increase of benthic organisms in the zooseston flux through this stretch was the result of the high inclination of the channel over the barrier, causing a higher water velocity and supporting the drift of benthic organisms.

Lotic stretches had a greater influence on the increase of abundance and biomass of benthic and semiplanktonic organisms than on the decrease of euplanktonic organisms. These lotic stretches in Plitvice Lakes are very short in comparison to the large lentic area. In 

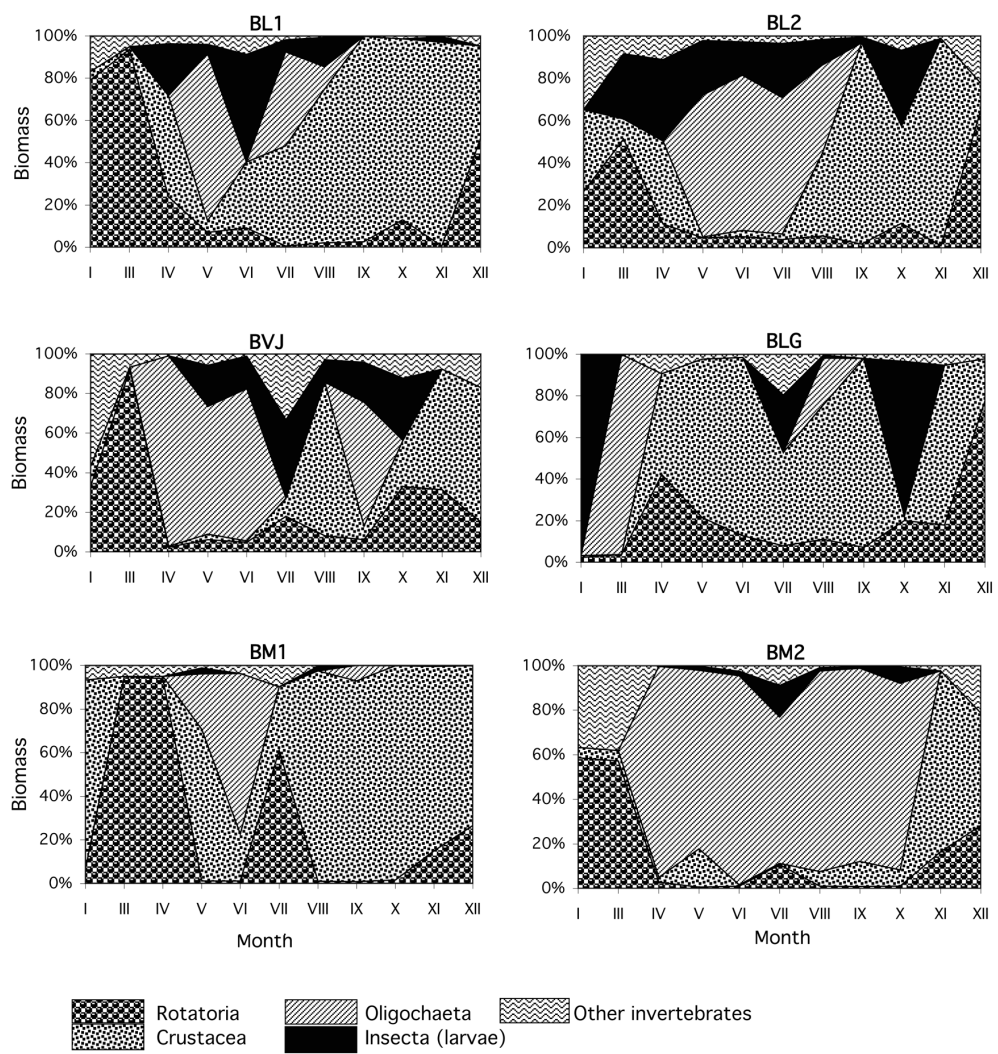

Fig. 6. Relative biomass of main taxonomic groups of zooseston at the sampling points of the Plitvice Lakes.

spite of that, the loss of euplanktonic organisms from seston by sedimentation, ingestion by macroinvertebrates, physical damage or mortality has the potential to change both the quality and quantity of zooseston.

In the lotic-lentic transition and flux of zooseston through the lake, a long retention time enables the sedimentation of larger benthic organisms (oligochaets, insect larvae, nematods). A slight increase of zooseston biomass and abundance appears to depend on the balance of gain and loss factors. Through Galovac Lake, high planktonic production equalised loss through the sedimentation of benthic organisms and their biomass was scarce. Also, riverine lakes such as the Plitvice Lakes, behave as a mixed reactor (chemostat) where organism abundance increases with water residence time (Walz \& Welker 1998). A significant relationship between water residence time and total zooplankton biomass (rotifers and crustaceans) was established in stu- dies by Basu \& Pick (1996) and Baranyi et al. (2002).

Along the longitudinal profile of the Plitvice Lakes, organisms in the zooseston originated primarily from lake plankton at the upper sections of the investigated station, and consequently, euplanktonic organisms made up the highest percentage of zooseston, which was dominated by rotifers and crustaceans. This is explained by the fact that rotifers, known as $r_{\max }$ strategists, are capable of occupying empty ecological niches in a short period of time, by very quickly adapting their life cycle to new ecological conditions (Walz 1995). Secondly, the water retention time in the Plitvice Lakes is sufficient for the reproduction of planktonic crustaceans, thereby contributing to an increase of biomass of euplanktonic organisms in the seston. Weglenska \& Ejsmont-Karabin (1994) investigated lentic and lotic parts of the Zegrzynski Reservoir. They established higher rotifer abundance and fecundities in lo- 
Table 3. Percentage of decrease or increase in abundance or biomass for life forms of zooseston organisms in the flux through the investigated stretches. Results of the non-parametric tests for differences in abundance and biomass of zooseston between the sampling points (Mann Whitney U-test) and between the investigated stretches (Kruskal-Wallis test)

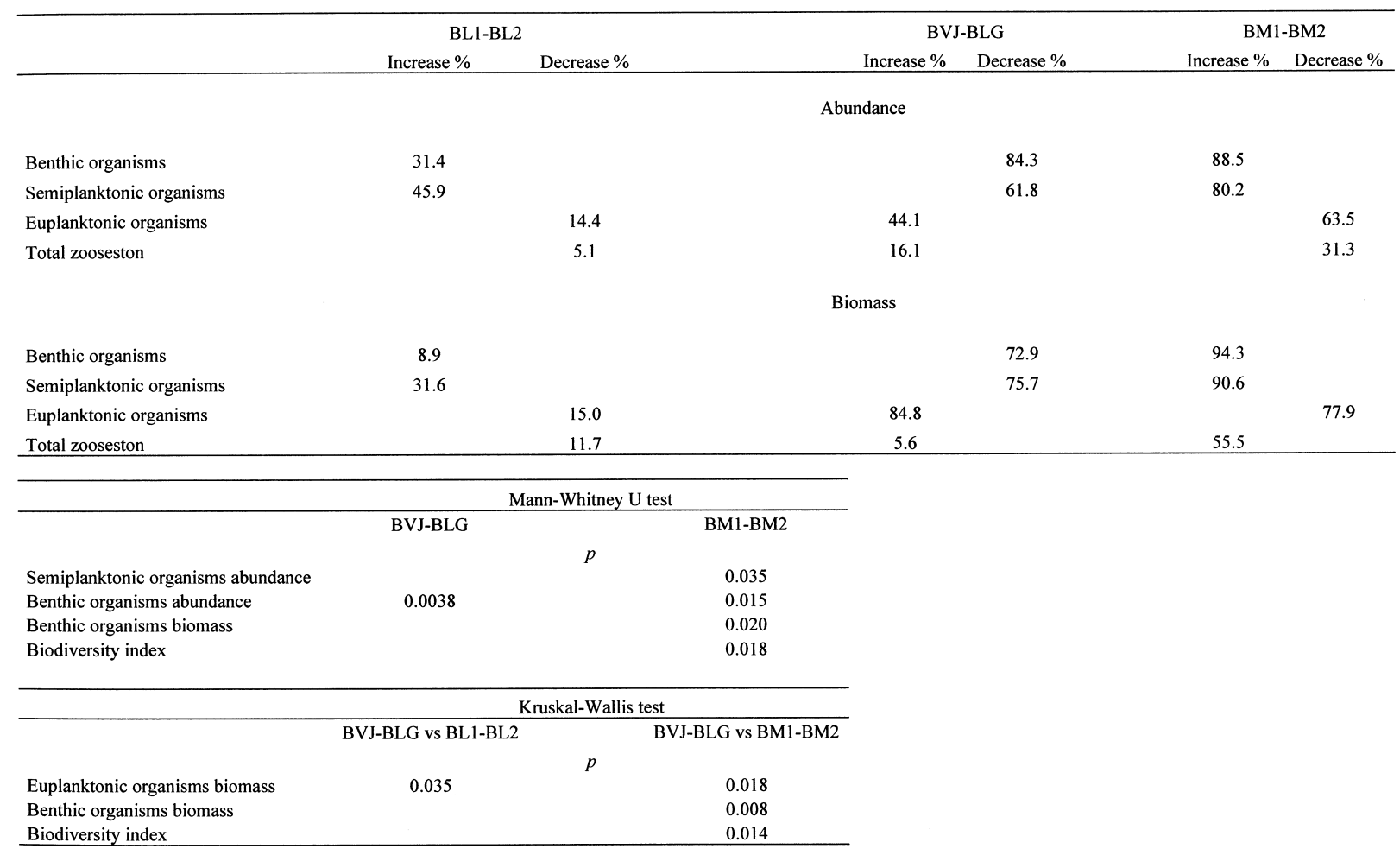

tic biotopes in comparison to the crustaceans that characterise lentic biotopes, and their fecundity mostly decreased in lotic biotopes. This coincides with the results of the present study, where crustaceans did not constitute an important percentage of zooseston abundance at stations with higher water velocity situated after waterfalls, such as BVJ and BM2, contrary to stations at lake outlets (BL1, BLG, BM1). The crustacean species, $T$. oithonoides and C. quadrangula both decreased in abundance after lotic stretches, though for copepod species, these decreases were more pronounced. Eriksson (2002) explained that the difference in resistance to hydraulic stress results from body shape. Namely, the author concluded that compact-bodied taxa, such as cladocerans, are more resistant to turbulent forces than copepods. These results support the fact that copepods avoid fast flowing water and prefer standing waters (Lair \& Reyes-Marchant 1997).

Biodiversity in the Plitvice Lakes is higher in comparison to other similar biotopes. For instance, 41 roti- fer species were found in the cascading lakes in the northern Cascade Mountains (Washington State, USA; Deimling et al. 1997). It can be presumed that karstic biotopes further contribute to this, with many microhabitats on the tufa barriers forming ecological niches for numerous benthic species. Such microhabitats are present in the Plitvice Lakes and the highest biodiversity was observed at the end of the lotic stretch. On the other hand, the flow of water from the lotic through the lentic biotopes decreased biodiversity. Therefore the Plitvice Lakes, semiplanktonic and benthic species most influenced biodiversity on the lotic stretches.

\section{Conclusions}

Zooseston flux through the Plitvice Lakes was influenced by environmental, hydrological and physiographical features of the lotic and lentic stretches, as well as food resources, especially algae, from the upstream lakes. The lotic stretches had a greater influence 
on the increase of abundance and biomass of benthic and semiplanktonic organisms than on the decrease of abundance and biomass of euplanktonic organisms. Consequently, euplanktonic organisms were dominant (50 to 95\%) in the flux through the three investigated stretches. In terms of zooseston abundance, rotifers and crustaceans prevailed, while crustaceans and benthic organisms prevailed in biomass. Higher resistance to water velocity was assumed in descending order for rotifers, cladocerans and copepods. According to the zooseston constitution, macrofilter-feeders prevailed over microfilter-feeders, indicating the low trophic degree of the lakes. Also, zooseston could contribute to a higher percentage to the mass of particulate organic matter, which in turn could influence tufa deposition and higher sedimentation rates on the barrier, respectively. Accordingly, a study of the quantitative effects of sedimentation and macroinvertebrate ingestion on the seston flux under varying hydrological conditions is planned.

\section{Acknowledgements}

We would like to thank Dr. Mladen Kučinić for his help in the collection of samples. This work was supported by the Ministry of Science and Technology, Republic of Croatia.

\section{References}

APHA 1985. - Standard methods for the examination of water and wastewater $\left(16^{\text {th }}\right.$ edition). Ed. Amer. Pub. Health Assoc., New York, $1268 \mathrm{p}$.

Basu B.K. \& Pick F.R. 1996. - Factor regulating phytoplankton and zooplankton biomass in temperate rivers. Limnol. Oceanogr., 41, 1572-1577.

Baranyi C., Hein T., Holarek C., Keckeis S. \& Schiemer F. 2002. Zooplankton biomass and community structure in a Danube River floodplain system: effects of hydrology. Freshw. Biol., 47, 473-482.

Breitig G. \& von Tümpling W. 1982. - Ausgewaehlte Methoden der Wasseruntersuchung, Band II. Biologische, mikrobiologische und toxikologische Methoden. VEB Gustav Fischer Verlag, Jena, 579 p.

Conde-Porcuna J.M., Ramos-Rodríguez E. \& Pérez-Martínez C. 2002. - Correlations between nutrient concentrations and zooplankton populations in a mesotrophic reservoir. Freshw. Biol., 47, 1463-1473.

Deimling E.A., Liss W.J., Larson G. L., Hoffman R.L. \& Lomnicky G.1997. - Rotifer abundance and distribution in the northern Cascade mountains, Washington, USA. Arch. Hydrobiol., 138, 345-363.

de Manuel J. \& Jaume D.1994. - Zooplankton from reservoirs of the Guadalquivir river basin (Spain). Arch. Hydrobiol. Suppl., 40, 107-116.

Descy J. P., Everbecq E., Gosselain V., Viroux L. \& Smitz S. 2003. Modelling the impact of benthic filter-feeders on the composition and biomass of river plankton. Freshw. Biol., 48, 404-417.

Dumont H.R. 1975. - The dry weight estimate of biomass in a selection of Cladocera, Copepoda and Rotifera from the plankton, periphyton and benthos of continental waters. Oecologia (Berl.), 19, 75-97.

Einsle U. 1993. - Crustacea, Copepoda, Calanoida und Cyclopoida. Gustav Fischer Verlag, Berlin, 209 p.

Erben R. 1991. - Vertical distribution of the rotifer fauna and its sea- sonal changes in the Plitvice Lakes, Croatia-Yugoslavia. Verh. Internat. Verein. Limnol., 24, 1066-1068.

Eriksson A.I., 2002. - Can predation by net-spining caddids larvae (Trichoptera: Hydropsyche siltalai) cause longitudinal changes in zooplankton species composition in lake outlet streams? Arch. Hydrobiol., 153, 231-244.

Foissner W. \& Berger H. 1996. - A user-friendly guide to the ciliates (Protozoa, Ciliophora) commonly used by hydrobiologists as bioindicators in rivers, lakes, and waste waters, with notes on their ecology. Freshwat. Biol., 35, 375-482.

Gilbert D., Amblard C., Bourdier G. \& Francez A..J. 1998. - Shortterm effect of nitrogen enrichment on the microbial communities of a peatland. Hydrobiologia, 373/374, 111-119.

Habdija I, Primc-Habdija B. \& Belinić I. 1994. - Functional community organization of macroinvertebrates in lotic habitats of the Plitvice Lakes. Acta Hydrochim. Hydrobiol., 22, 85-92.

Habdija I., Primc-Habdija B., Matoničkin R., Kučinić M., Radanović I., Miliša M. \& Mihaljević Z. 2004. - Current velocity and food supply as factors affecting the composition of macroinvertebrates in bryophyte habitats in karst running water. Biologia, Bratislava, $59,577-593$.

Karabin A. 1985. - Pelagic zooplankton (Rotatoria + Crustacea) variation in the process of lake eutrophication. II Modifing effect of biotic agents. Ecol. Pol., 33, 617-644.

Lair N. 1980. - The rotifer fauna of the River Loire (France), at the level of the nuclear power plants. Hydrobiologia , 73, 153-160.

Lair N. \& Reyes-Marchant P. 1997. - The potamoplankton of the Middle Loire and the role of the "moving littoral" in downstream transfer of algae and rotifers. Hydrobiologia, 356, 33-52.

Leonard J. A. \& Paerl H.W. 2005. - Zooplankton community structure, micro-zooplankton grazing impact, and seston energy content in the St. Johns river system, Florida as influenced by the toxic cyanobacterium Cylindospermopsis raciborskii. Hydrobiologia, 537, 89-97.

Malley D.F., Lawrence S.G., Maclver M. A. \& Findlay W. J. 1989. Range of variation in estimates of dry weight for planktonic Crustacea and Rotifera from temperate North American Lakes. Can. Tech. Rep Fish. Aquat. Sci., 1666, 1-49.

McCune B \& Mefford M.J. 1999. - PC-ORD. Multivariate analysis of ecological data, Version 4. MjM Software Design, Gleneden beach, Oregon, USA, $237 \mathrm{p}$.

Nusch E.A. 1980. - Comparison of different methods for chlorophyll and phaeopigment determination. Arch. Hydrobiol. Suppl., 14, 14-36.

Ogden C.G. \& Hedley R.H. 1980. - An atlas of freshwater Testate Amoebae. British Museum (Natural History) and Oxford University Press, London and Oxford, 222 p.

Pozo J., Elosegui A. \& Basaguren A. 1994. - Seston transport variability at different spatial and temporal scales in the Agüera watershed (North Spain). Wat. Res., 28, 125-136.

Sandlund O.T. 1982 - The drift of zooplankton and microzoobenthos in the river Strandaelva, western Norway. Hydrobiologia, 94, 33-48.

Shannon C.E. \& Weaver W. 1949. - The mathematical theory of communication. University of Illinois Press, Urbana, $117 \mathrm{p}$.

Srdoč D., Horvatinčić N., Obelić I., Krajcar-Bronic I. \& Sliepčević A. 1985. - Calcite deposition processes in karst waters with special emphasis on the Plitvice lakes, Yugoslavia. Carsus Iugoslaviae, 11, 101-204.

Śpoljar M. 2003. - Transport of the seston in the cascading system of the Plitvice Lakes. PhD. University of Zagreb, Faculty of Science, Zagreb, $156 \mathrm{p}$.

Špoljar M., Primc-Habdija B.\& Plenkovic-Moraj A. 2001. - Overflow effect on the dynamics of the rotifer community in cascade lake systems. Verh. Internat. Verein. Limnol., 27, 3409-3412. 
Tubbing G.M.J., Admiraal W., Backhaus D., Friedrich G., de Ruyter van Steveninck E.D., Mueller D. \& Keller I 1994. - Results of the international plankton investigation on the River Rhine. Wat. Sci. Tech., 29, 9-19.

Vadeboncoeur Y. 1994. - Longitudinal dynamics of seston concentration and composition in a lake outlet stream. J.N.Am. Benthol. Soc., 13, 181-189.

Voigt M. \& Koste W. 1978. - Rotatoria. Die Rädertiere Mitteleuropas. II vol Gebrüder Borntraeger, Berlin, Stuttgart, 673 p./234 ill.p.

Walz N. 1995. - Rotifer populations in plankton communities: energetics and life history strategies. Experientia, 51, 437-453.
Walz N. \& Welker M. 1998. - Plankton development in a rapidly flushed lake in the River Spree system (Neuendorfer See, Northeast Germany). J. Plankon Res., 20, 2071-2087.

Weglenska T. \& Ejsmont-Karabin J. 1994. - The short and long term variability of the zooplankton structure in the Zagrzynski reservoir. Arch. Hydrobiol. Suppl., 40, 117-126.

Welker M. \& Walz N. 1998. - Can mussels control the plankton in rivers? - a planktological approach applying a Lagrangian sampling strategy. Limnol. Oceanogr., 43, 753-762. 